\title{
IDEA ZRÓWNOWAŻONEGO ROZWOJU W HOTELARSTWIE NA PRZYKŁADZIE SIECI RADISSON BLU
}

\section{Wstęp}

Ekologia, czyli dbanie o równowagę w środowisku przyrodniczym, w ostatnich latach stała się istotnym elementem życia społecznego, niezależnie od tego, jak bardzo ludzie angażują się w nią na co dzień. Nawet segregacja śmieci jest już działaniem proekologicznym, a akcje uzmysławiające, jak groźne może być np. nadużywanie plastiku, zwiększają świadomość ekologiczną.

Pojęciem szerszym od ekologii jest zrównoważony rozwój. Działania podejmowane $w$ ramach tego zagadnienia mają na celu stworzenie mechanizmów, dzięki którym cywilizacja będzie się rozwijać z poszanowaniem dla praw przyrody oraz przyjętych zasad społeczno-gospodarczych (Skowroński, 2006). Organizacja Narodów Zjednoczonych wskazała 17 celów zrównoważonego rozwoju. Wśród nich znajdują się te z zakresu ochrony środowiska naturalnego, gospodarki, jak również społeczeństwa (rys. 1).

W hotelarstwie przez lata wypracowano działania mające na celu redukowanie negatywnego wpływu funkcjonowania obiektu na otoczenie samego hotelu i na jego gości. Sieć Radisson Blu jest doskonałym przykładem tego, jak wiele metod, ograniczających zużycie energii oraz wody czy wpływających na zmniejszenie ilości odpadów, można wykorzystać w obiekcie hotelowym. Ponadto sieć angażuje się w akcje prospołeczne oraz chętnie uczestniczy w testowaniu nowych rozwiązań proekologicznych. 


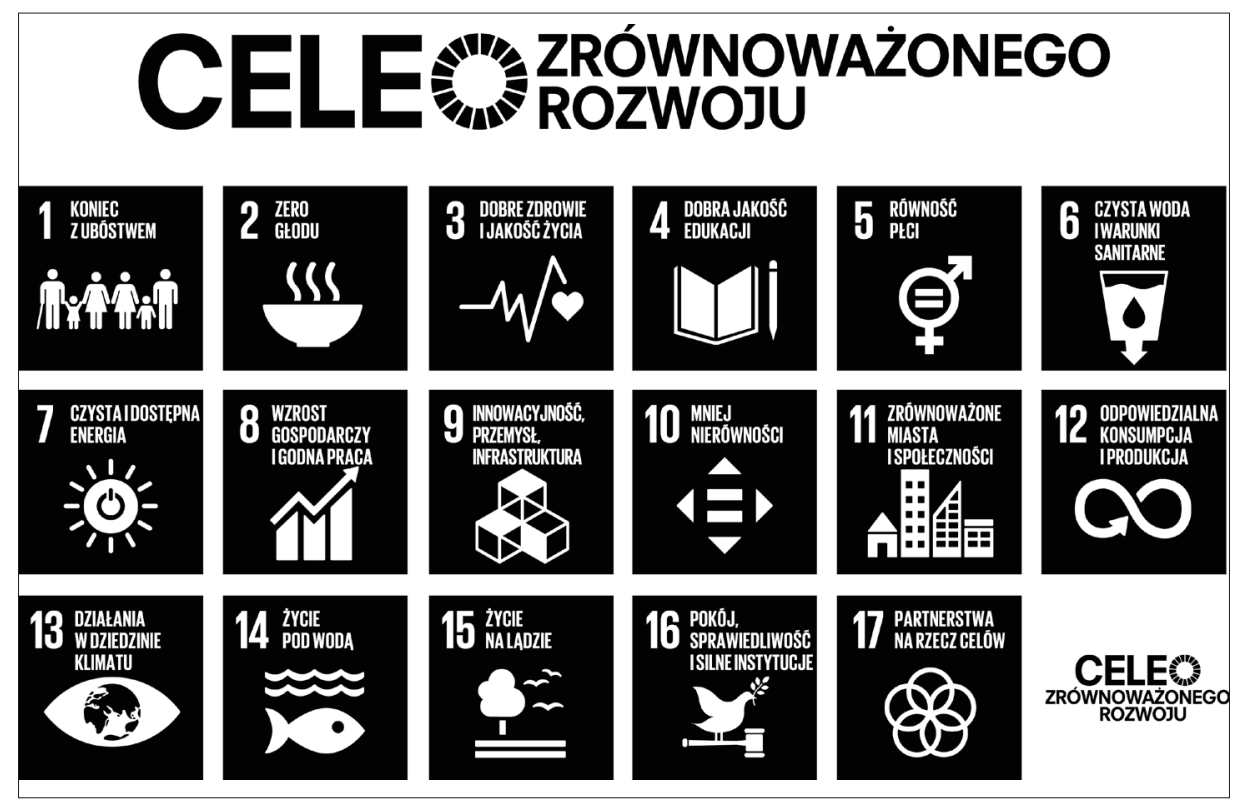

Rysunek 1. Cele zrównoważonego rozwoju Źródło: Cele zrównoważonego rozwoju (2019)

\section{Zrównoważony rozwój w turystyce}

Obecnie zauważalna stała się nieunikniona potrzeba zmiany stosunku między turystyką a ochroną środowiska, powstało wiele organizacji wspomagających idee zrównoważonego rozwoju. Działają one zarówno na obszarach regionów turystycznych, jak i w samych obiektach hotelarskich. Dzięki wielu dostępnym certyfikatom hotelarze mogą wyróżnić się na rynku, kreując pozytywny wizerunek swojej marki.

W 1992 r. na konferencji Organizacji Narodów Zjednoczonych, dotyczącej środowiska i rozwoju, powołano International Hotels Environment Initiative, działającą obecnie pod nazwą International Tourism Partnership (ITP) (zob. International Tourism Partnership, 2019). Misją tej organizacji jest zapewnienie dostępu do wiedzy z zakresu odpowiedzialności środowiskowej i społecznej oraz pokazanie przedstawicielom branży turystycznej, że dbanie o środowisko ma nie tylko pozytywny wpływ na otoczenie, ale również na biznes. Od 1993 r. członkowie ITP tworzą specjalny przewodnik dla hoteli, poświęcony jakości zarządzania środowiskiem - Environmental Management for Hotels. Ponadto w 1995 r. powstało czasopismo „Green Hotelier Magazine”, z którego hotelarze z całego świata 
mogą czerpać wiedzę o zrównoważonym rozwoju oraz odpowiedzialności środowiskowej. Aby jeszcze bardziej ułatwić zrozumienie działań, które można podjąć w ramach ochrony natury poprzez uczestnictwo w programie Going Green, ITP w 2007 r. opublikowało zaledwie czterostronicową broszurę, która w prosty sposób informuje, jak krok po kroku zorganizować hotel bardziej przyjazny środowisku (History, 2019).

Komisja Europejska, w ramach promocji zrównoważonego rozwoju w Europie, w 2006 r. uruchomiła program z dziedziny turystyki pod nazwą European Destinations of Excellence (EDEN). Co roku z każdego kraju uczestniczącego w konkursie wybierany jest jeden modelowy ośrodek turystyczny. Celem projektu jest stworzenie listy miejsc w Europie, które charakteryzują się szczególnymi walorami dziedzictwa przyrodniczego i kulturowego. Poza aspektami promocyjnymi EDEN przyczynia się do równomiernego rozłożenia ruchu turystycznego. Dzięki temu programowi turyści zaczynają się interesować nowo odkrytymi miejscami, wyłonionymi w ramach konkursu, co skutkuje odciążeniem najbardziej znanych i obleganych dotychczas ośrodków (EDEN, 2019).

Od 2017 r. hotele, pensjonaty oraz kempingi mogą ubiegać się o europejski certyfikat Ecolabel, którego celem jest dbanie o minimalizowanie negatywnego wpływu na środowisko. Aby otrzymać ten certyfikat, obiekty muszą spełnić wiele wymogów dotyczących ograniczenia zużycia surowców. Obowiązkowe jest też wyposażenie w energooszczędne urządzenia oraz wodooszczędną armaturę. Ponadto wymagane jest ograniczenie liczby prań, a wymiana pościeli i ręczników nie powinna odbywać się codziennie. Dodatkowo eliminuje się produkty jednorazowego użytku, takie jak: szczoteczki do zębów, czepki pod prysznic czy ręczniki papierowe. $\mathrm{W}$ odniesieniu do gastronomii certyfikat Ecolabel zobowiązuje przedsiębiorców do zmniejszenia do minimum ilości odpadów spożywczych poprzez racjonalne zarządzanie dostawami. Poza tym, zgodnie ze wspomnianą normą, niektóre produkty, takie jak cukier czy kawa, nie mogą być serwowane w pojedynczych opakowaniach (Włącz oszczędzanie, 2019).

\section{Programy realizowane w sieci Radisson Blu}

Sieć Radisson Blu, należąca do Radisson Hotel Group, działa od 2010 r. Zarządcy obiektów tej sieci szczycą się faktem, że co trzeci hotel działa zgodnie z założeniami ekologicznymi oraz że Radisson Blu jest jednym z najbardziej etycznych przedsiębiorstw hotelowych na świecie 
(Radisson Hospitality Development, 2019). Dodatkowo w tej sieci hoteli prowadzony jest szereg działań w zakresie odpowiedzialnego biznesu, w które zaangażowani są goście i pracownicy. Do podejmowanych tam inicjatyw należy m.in.: dbanie o energooszczędne oświetlenie, wykorzystywanie wody $\mathrm{z}$ basenów $\mathrm{w}$ ogrodach oraz zachęcanie do rzadszej wymiany ręczników.

Goście są motywowani do podejmowania działań w ramach zrównoważonego rozwoju, np. poprzez ograniczanie wpływu konferencji na środowisko. Na etapie planowania spotkania istnieje możliwość obliczenia ilości dwutlenku węgla, który zostanie wytworzony w trakcie trwania konferencji. W hotelu proponuje się organizatorom zmianę lokalizacji ze standardowej sali konferencyjnej na plenerowa, skorzystanie z akcji sadzenia drzew przez uczestników oraz jazdę próbną samochodami elektrycznymi.

Inną inicjatywą sieci jest „Soap for hope”. Akcja ma na celu dostarczenie mydła do społeczeństw, w których jego brak jest powodem wielu chorób, prowadzących do śmierci dzieci. Z mydeł w kostkach, używanych w hotelach sieci Radisson Blu, powstaje corocznie prawie dwa miliony ton odpadu mydlanego. Aby zapobiec marnowaniu surowca, niezużyte kostki są przetwarzane i przekazywane do miejsc, w których występują problemy z higieną (Odpowiedzialność społeczna, 2019).

Sieć w wyjątkowy sposób zachęca również swoich gości do ograniczania wymiany ręczników. Za każdym razem, gdy ktoś zrezygnuje z prania, hotel przekazuje darowiznę na rzecz międzynarodowej fundacji Just a Drop, która zwalcza problem braku dostępu do wody pitnej na świecie. Za każde 500 użytych ponownie ręczników sieć zapewnia wodę pitną na całe życie dla jednego dziecka. Dodatkowo ograniczenie liczby prań przyczynia się do oszczędzania wody oraz zmniejszenia wpływu detergentów na środowisko.

Efektywne dbanie o środowisko wymaga wypracowania własnych, innowacyjnych metod. W 2016 r. sieć wspólnie z firmą Diversey Care prowadziła badania nad nowoczesnymi środkami chemicznymi do prania, które redukują wpływ hotelowych pralni na środowisko. Zastosowana w tych środkach technologia umożliwia pranie w niższych temperaturach oraz sprawia, że nie jest wymagane intensywne płukanie. Dzięki temu zmniejsza się zużycie energii, skraca się czas pracy i następuje redukcja poboru wody nawet o $26 \%$. Badania zostały przeprowadzone w hotelu w Dubaju, a wspomniane środki chemiczne są sukcesywnie wprowadzane w kolejnych obiektach (Case study..., 2019). 


\section{Działania sieci Radisson Blu w Polsce}

W hotelach w Polsce, oprócz ogólnych inicjatyw realizowanych przez całą sieć Radisson Blu, podejmowane są również indywidualne działania na rzecz lokalnej społeczności. Na oficjalnych stronach internetowych niektórych $\mathrm{z}$ tych hoteli publikowane są informacje o inicjatywach oraz akcjach, w których owe obiekty biorą udział.

Jednym z hoteli, który udziela się lokalnie, jest obiekt w Krakowie. Jest to jedyny hotel w Polsce, w którym odbywają się spotkania spełniające wymagania certyfikatu BS8901, co skutkuje redukcją wpływu konferencji i bankietów na środowisko i miejscową ludność (Radisson Blu Hotel, Kraków, 2019). Norma ta obowiązuje od 2007 r. i odnosi się do zarządzania eventami w sposób zrównoważony, z dbałością o środowisko oraz względy ekonomiczne czy społeczne (Zielone wydarzenia, 2019). W 2012 r. Hotel Radisson Blu Kraków wraz z przedsiębiorstwem finansowym UBS oraz Fundacją Jaśka Meli „Poza Horyzonty” zorganizował w Krakowie pierwszy bieg „Poland Bussines Run”. Co roku w trakcie tego wydarzenia zbierane są pieniądze dla konkretnych podopiecznych fundacji. Obecnie bieg jest organizowany już w dziewięciu miastach (Poland Business Run, 2019). Co ciekawe, w okresie przedświątecznym w lobby krakowskiego hotelu Radisson Blu jest umieszczana choinka z wyjątkowymi bombkami. W ich wnętrzu znajdują się listy do Świętego Mikołaja napisane przez podopiecznych domu dziecka. Każdy może zerwać taką bombkę, kupić prezent i spełnić ich marzenia (Podgórze.pl, 2019).

Również w przypadku hotelu w Szczecinie udostępniane są informacje o jego działaniach. Corocznie obiekt jest zaangażowany w Światowy Dzień Wody oraz bierze udział w akcji "Godzina dla Ziemi”, podczas której gaszone są światła zewnętrzne oraz część oświetlenia wewnątrz obiektu. Zatrudnione w hotelu osoby angażują się w takie wydarzenia, jak „Sprzątanie Ziemi” czy „Sprzątanie lasu”, oraz uczestniczą w charytatywnych maratonach. Ponadto pracownicy szczecińskiego Radisson Blu wraz ze Stowarzyszeniem Przyjaciół Dzieci Niepełnosprawnych „Przyjazna 18” organizują w Gimnazjum nr 18 w Szczecinie warsztaty poświęcone osobom niepełnosprawnym. Co więcej, między hotelem a Polskim Stowarzyszeniem na rzecz Osób z Upośledzeniem Umysłowym została zawarta umowa, w której wyniku przyjęto do pracy w obsłudze pięter oraz kuchni osoby niepełnosprawne.

Kolejnym obiektem zaangażowanym w lokalne akcje w ramach odpowiedzialnego biznesu jest Radisson Blu Sobieski w Warszawie. Jego 
pracownicy corocznie biorą udział w "Sprzątaniu świata" czy w akcji organizowanej z okazji Światowego Dnia Świadomości Autyzmu, a od 2014 r. również w biegu „Poland Business Run”. Ponadto hotel sprawuje całoroczną opiekę nad Domem Dziecka przy ul. Tarczyńskiej. W ramach pomocy placówce z inicjatywy Hotelu Sobieski organizowane jest m.in. zwiedzanie Warszawskich Filtrów, czyli miejskiej stacji wodociągowej, podczas którego realizowane są akcje edukacyjne związane z ochroną zasobów wodnych (Radisson Blu Sobieski Hotel, Warszawa, 2020).

Hotel we Wrocławiu jest zaangażowany przede wszystkim w sprawy społeczne. Jest partnerem programu Polskiego Czerwonego Krzyża „Bardzo Dobre Maniery", polegającego na tym, że jeśli gość hotelowy, kończąc posiłek w restauracji, skrzyżuje sztućce na talerzu, to do jego rachunku zostanie doliczone 5 złotych, które będzie przekazane na pomoc niedożywionym dzieciom (Kampania..., 2019). Natomiast w ramach działań na rzecz ochrony środowiska goście hotelu są zachęcani do przekazywania punktów ze swoich kart lojalnościowych na program zalesiania Kenii (Radisson Blu Hotel, Wrocław, 2019).

\section{Podsumowanie i wnioski}

Świadomość proekologiczna rośnie, a co za tym idzie - konsumenci stają się pod tym względem bardziej wymagający, przedsiębiorcy zaś starają się temu sprostać. W tym kierunku podąża też branża hotelarska, w której wprowadzane są istotne zmiany w zarządzaniu obiektami. Energooszczędne oświetlenie, segregacja odpadów czy armatura ograniczająca zużycie wody stają się już standardem. Co więcej, hotelarze zaczęli wdrażać swoje własne rozwiązania, prowadzące do ochrony środowiska.

Warto podkreślić, że zarządcy hoteli nie są pozostawieni sami sobie, ponieważ mogą korzystać z norm i zasad wypracowanych przez lata przez Unię Europejską i wiele instytucji z nią związanych. Obiekty hotelowe mają szansę wyróżnić się na rynku, uzyskując certyfikaty, takie jak np. Ecolabel, w zamian za przestrzeganie norm przyznających je organizacji proekologicznych.

Hotelarze starają się również wykorzystywać rozpoznawalność swoich obiektów do szerzenia dobrych nawyków. Włączają się w akcje, takie jak „Sprzątanie świata" czy "Godzina dla Ziemi”. Dodatkowo dbają o dobro swojego otoczenia, biorąc udział w wydarzeniach, podczas których np. zbierają środki na rzecz podopiecznych lokalnych organizacji charytatywnych, lub organizując samodzielnie takie eventy. 
Goście coraz bardziej doceniają starania hotelarzy w zakresie ochrony środowiska, a działania, które są promowane w hotelach, nie uchodzą ich uwadze. $W$ ramach odpowiedzialnego biznesu podejmowanych jest wiele inicjatyw proekologicznych na różnych płaszczyznach. Wpływają one korzystnie m.in. na społeczeństwo zarówno lokalnie, jak i globalnie, a także na środowisko naturalne. Dzięki działaniom zarządców hoteli, ich pracowników oraz gości, minimalizuje się negatywny wpływ rozwoju gałęzi usług, jaką jest hotelarstwo. Co więcej, wprowadzanie rozwiązań ekologicznych w hotelach opłaca się w dwójnasób - jest ono gwarantem bezpieczeństwa natury i oszczędności pieniędzy hotelarzy.

\section{Bibliografia}

Case study: lowering laundry's impact. Reducing the environmental footprint of hotel operations at Radisson Blu through the Clax Advanced laundry solution (2019). Pobrane z: https://cache.radissonhotels.com/galleries/radblu/galleries/radblu/images/PDF/ SealedAir_RadissonBlu_CaseStudy_FINAL.pdf (1.03.2019).

Cele zrównoważonego rozwoju (2019). Pobrane z: http://www.un.org.pl/ (21.12.2019).

EDEN (2019). Pobrane z: https://www.edenpolska.pl/pl/o-projekcie-eden2 (22.01.2019).

International Tourism Partnership (2019). Pobrane z: https://www.ihei.org/about-us/ (22.01.2019).

History (2019). Pobrane z: https://www.ihei.org/about-us/history/ (22.01.2019).

Kampania: „Bardzo Dobre Maniery” (2013). Pobrane z: https://dziennikpolski24.pl/kampania-bardzo-dobre-maniery-z-pck/ar/3274262 (26.04.2019).

Odpowiedzialność społeczna (2019). Pobrane z: https://www.radissonblu.com/pl/responsible (28.03.2019).

Podgórze.pl (2019). Pobrane z: https://podgorze.pl/dom-dziecka-przy-alei-pod-kopcem/ (25.04.2019).

Poland Business Run (2019). Pobrane z: https://polandbusinessrun.pl/pl/pbr/about/historia-1 (25.04.2019).

Radisson Blu Hotel, Krakow (2019). Pobrane z: www.radissonblu.com/pl/hotel-krakow/ responsible-business (10.08.2020).

Radisson Blu Hotel, Wrocław (2019). Pobrane z: www.radissonblu.com/pl/hotel-wroclaw/ responsible (10.08.2020).

Radisson Blu Sobieski Hotel, Warszawa (2020). Pobrane z: www.radissonblu.com/pl/ sobieski-warsaw (10.08.2020).

Radisson Hospitality Development (2019). Pobrane z: https://www.radissonhospitalityab. com/development (10.08.2020).

Skowroński, A. (2006). Zrównoważony rozwój perspektywą dalszego postępu cywilizacyjnego. Problemy ekorozwoju, 1 (2), 47-57.

Włącz oszczędzanie (2019). Pobrane z: https://wlaczoszczedzanie.pl/znaki-ekologiczne/ oznaczenia-produktow-ekologicznych/ecolabel-zwany-tez-stokrotka-lub-margerytka/ (22.01.2019).

Zielone wydarzenia (2019). Pobrane z: https://zielonewydarzenia.pl/pl/i.7.id.564.0/Brytyjski_standard_BSI_8901.html (25.04.2019). 


\title{
IDEA ZRÓWNOWAŻONEGO ROZWOJU W HOTELARSTWIE NA PRZYKŁADZIE SIECI RADISSON BLU
}

\begin{abstract}
Abstrakt: Artykuł ma na celu ukazanie sposobów realizowania idei zrównoważonego rozwoju w sektorze hotelarstwa. Zagadnienie zostało omówione na przykładzie sieci Radisson Blu oraz podejmowanych w niej autorskich działań w zakresie zachowania równowagi przyrodniczej oraz wprowadzanych programów prospołecznych. Dodatkowo $\mathrm{w}$ artykule opisano związane $\mathrm{z}$ tym praktyki stosowane $\mathrm{w}$ poszczególnych hotelach tej sieci na terenie Polski.
\end{abstract}

Słowa kluczowe: zrównoważony rozwój, ekologia, hotelarstwo, Radisson Blu.

\section{THE IDEA OF SUSTAINABLE DEVELOPMENT IN THE HOSPITALITY SECTOR: THE EXAMPLE OF THE RADISSON BLU NETWORK}

\begin{abstract}
The purpose of the article is to present ways of implementing the idea of sustainable development in the hospitality sector. The issue was discussed using the example of the Radisson Blu network and its activities with regard to maintaining sustainable practices and implementing pro-social programs. In addition, the author has described some practices implemented in individual hotels of this network in Poland.
\end{abstract}

Keywords: sustainable development, ecology, hotel sector, Radisson Blu. 